DOI 10.47315/archives2020.325.026

УДК 94:930.25](100)

Larysa Levchenko

Doctor of Historical Sciences,

Professor,

Deputy Head,

State Archival Services of Ukraine;

Professor of the Department of History,

Black Sea National University named after Petro Mohyla

ORCID: https://orcid.org/0000-0001-9097-7373

\title{
A SAMPLE OF PERIODIZATION OF THE UNIVERSAL HISTORY OF ARCHIVES IN THE LIGHT OF CIVILIZATION APPROACH AND EVOLUTION OF DATA MEDIUM*
}

\begin{abstract}
The purpose of the study is to develop a version of the periodization of the Universal history of archives, taking into account the civilizational approach and the evolution of the data medium. The research methodology is based on the proposals of the Soviet-Russian historian-archivist Eugeny Starostin concerning the significance of the data medium for periodization of the Universal history of archives and the ideas of civilizationists. The scientific research is new in the development of the periodization of the Universal history of archives in a horizontal plane, which takes into consideration the interaction and mutual influences of civilizations as well as demonstrates the results of their archival efforts. Also, the author identifies a data medium typical for each civilization. Conclusion. Applying a civilizational approach to develop the periodization of the Universal history of archives, scientists are not limited to building linear (rising) models with rigid links between components. Since each civilization is a unique, autonomous, selfsufficient, and self-governing system, it is possible to create a horizontal model of the periodization of the history of archives. In this case, the scholars can integrate more civilizations in the horizontal model or separate them into subgroups without difficulty.

Human history demonstrates the mutual influence of civilizations; civilizational conflicts often have devastating consequences in the field of preserving the collective
\end{abstract}

* Текст статті друкується в авторській редакції.

(C) Л. Левченко, 2020 
human memory and transferring it to future generations. Sometimes, civilizations destroy their historical heritage voluntarily. However, in general, the archives are often taken away by the implacable brutality of the time. In this context, the nature of the information data medium plays a decisive role in the periodization of the Universal history of archives. The function of documents storage is mainly determined by the nature of the data media.

In the presented version of the periodization, 10 civilizations are taken into account, including the modern civilization. Each possessed specific typical data media identified below. Thus, the offered version of periodization is as follows: «the epoch of clay tablets» - Mesopotamian civilization (6000-300 BC); «the epoch of papyrus» - Egyptian civilization (5500-300 BC); «the epoch of the wooden tabula» - Greco-Roman (classical) civilization (1500 (1100) BC - (500) 600 AD); «the epoch of steatite tablets» - the Indus Valley (Harappa) civilization (37001300 BC); «the epoch of bamboo slips» - the Ancient Chinese Civilization (2000 $\mathrm{BC}-400 \mathrm{AD})$; «the epoch of Amate» - the Mesoamerican civilization (1000 BC $1550 \mathrm{AD}$ ); «the epoch of khipu» - the Andean civilization (3700-1800 BC); «the epoch of tanned parchment» - the Byzantine civilization (395-1453); «the epoch of paper» - Northwest Old World (Western, Orthodox and Islamic) civilization (from Christmas to the end of XX cent.); «the epoch of digital data medium» - modern civilization (from the late XXth - early XXI cent. and going)

Key words: Universal history of archives; periodization of archives history; archives of civilizations.

In spite of the dream of living forever, humans are mortal in the physical sense. There is no reliable method of continuing human life except giving birth to children and providing them with information about their culture and ancestry. In this context, archives play a considerable role because they can save and transfer the collective human memory from one generation to the next.

The contemporary archival science states that first archives appeared in the middle of IV millennium BC after the written-language civilizations had emerged; however, some scientists point out that the so-called oral archives existed in the preliterate civilizations. The periodization is a result of conditional separation of the historical process into chronological periods. In the history of archives, the periodization has value beyond the identification of periods and their sequence. It helps comprehend the distinctive characteristics and features of every period. The periodization helps scholars realize the results of efforts undertaken by humankind for the preservation of collective memory attained at the end of every period as well as tracing of the following influence on further humanity history development. The analysis of outcomes allows us to predict whether modern civilization's efforts to preserve and transfer knowledge and information to the next generations would be successful. The determining factor for the periodization of archives history is the choice of criteria that can serve as its basis. 
This article does not have a goal to examine all existing variants of archives history periodization, because the majority of them are Eurocentric. Moreover, a professor of the Hamburg University doctor Markus Friedrich estimated them in his book «The Birth of the Archive: A History of Knowledge». He concluded that Eugenio Casanova ${ }^{1}$, Adolf Brennecke ${ }^{2}$, Leopoldo Sandri ${ }^{3}$, Elio Lodolini ${ }^{4}$, Robert-Henri Bautier ${ }^{5}$ as well as Jose Luis Rodriguez de Diego ${ }^{6}$ had elaborated their theories on the basis of the European archives history and «none of these periodizations of the history of archives is completely satisfactory» including the outstanding Bautier's periodization ${ }^{7}$. It is known that Bautier had subdivided the Universal history of archives into four periods: «the palace archives period» (the Ancient Times), «the chartulary period» (the XII-XV centuries), the period of «archives as authority armory» (from the XVI to the early XIX century) and the period of «archives as laboratories of history» (the early XIX to the XX century). M. Friedrich criticized Bautier because he had ignored completely private and ecclesiastical efforts to preserve archives. He insisted that Bautier could have found much more persuasive arguments to identify the new stage in the history of European archives than the first appearance of central state archives. For instance, it could have been the first publications of archival treatises started after 1571. M. Friedrich developed an idea that archival records had become a part of people's daily life long before the Early Modern Period.

Having considered the previous periodizations, the purpose of this study is developing a version of periodization of the Universal history of archives, taking into account the civilizational approach and the evolution of data medium.

The research methodology follows the proposals of the Soviet-Russian historian-archivist Eugeny Starostin concerning the significance of data media for the periodization of the Universal history of archives and ideas of civilizationists. In addition, it was possible to identify a data medium typical

1 Casanova Eugenio. Archivistica. 2-a Edizion. Siena, 1928. 533 p.

2 Brenneke Adolf. Archivistica. Contributo Alla Teoria ed Alla Storia Archivistica Europea. Milano, MCMLXVIII. 666 p.

3 Sandri Leopoldo. La storia degli archive. Istituto Polografico dello Stato, 1958. $134 \mathrm{p}$

4 Lodolini Elio. Lineamenti di storia dell'archivistica italiana. Dalle origini alla metà del secolo XX. 1991. 260 p.; Lodolini Elio. Storia dell'archivistica italiana. Dal mondo antico alla metà del secolo XX. Franco Angeli, 2018. 368 p.

5 Bautier Robert-Henri. La phase cruciale de l'histoire des archives: la constitution des dépôs d'archives et la naissance de l'archivistique (XVIe - début du XIXe siècle) // Archivum. Vol. XVIII (1968). Paris, 1970. P. 139-149.

6 Rodriguez de Diego José Luis. Evolución histórica del expediente // Anuario de historia del derecho español. № 68. 1998. P. 475-490.

7 Friedrich Markus. The Birth of the Archive: A History of Knowledge / trans. by John Noel Dillon. Ann Arbor, 2018. P. 13-14. 
for each civilization. Therefore, this version of periodization can demonstrate the effectiveness of the methods used to preserve the documentary heritage distinctive for each civilization. Research pays special attention to the fact that the civilizational approach views the historical process as the mutually influential interaction of civilizations.

This investigation has emerged from the previous research of E. Starostin who was a close friend and passionate opponent of Robert-Henri Bautier. Unfortunately, Markus Friedrich mentions nothing about the periodization proposed by E. Starostin. Of course, the periodizations elaborated by Soviet scholars suffered from the influence of the Marxist concept of socioeconomic formations which was fundamental to historical materialism. Nevertheless, modern scientists use similar approaches in their theory construction. Today, scholars rely upon the division of the Universal history of archives into conventional periods with regard to the generally accepted periodization of World history (ancient history, the Middle Ages, modern history, etc.). In such a way, they ignore the nature and specific features of archives. This situation stems from the methodology of World history that adopted the linear (rising) development principle.

In the view of E. Starostin, even the most advanced authors, such as Brennecke and Bautier, were not able to create the integrated principle of classification by using such methodology. They failed to develop the universal theoretical scheme which would have been suitable for other regions of the World. E. Starostin emphasized that his foreign colleagues had developed the models of archives history solely in the context of their countries' history (Germany and France).

To create his own periodization, E. Starostin extracted two fundamental functions genetically intrinsic to archives: the preservation and search of documents. Moreover, E. Starostin determined three periods in the Universal history of archives. The first period, from the birth of archives to the XVI - the beginning of the XVII century, was characterized by the underdevelopment of the state apparatus inside of which archives were not independent establishments but parts of chancelleries. The historical documents were often kept together with treasures and other property of monarchs. The search aids were fairly primitive. E. Starostin opined that after book printing appeared, narrative and documental sources were divided into separate groups, and each of these groups received a specific place for storing. The second period (from the XVI-XVII centuries to the edge of XIX-XX centuries) was marked by the creation of numerous and varied archival holdings, and establishment of archives as repositories of legal documents. At the end of this period, the function of storage was balanced by the function of searching, and archives became laboratories of history. During the third period, archives were separated from the state apparatus and became a detached branch of state administration. The archival branch reflected the administrative and 
territorial structure of countries, the system of state administration, cultural and legal traditions and customs of the society and a growing role of archival documents in the defense of individual and common rights of citizens. The functions of archives broadened to include accession and appraisal, control over record-keeping and documents during whole life-cycle. The archives started collecting and storing documents with nontraditional data media, etc. The profession of archivist had grown up from intellectual workmanship and gained public character. The archives were included in the international information area, the interstate archival cooperation began, and, finally, the «archival science» development started up.

Nevertheless, E. Starostin pointed out clearly in his conclusion that the history of archives had gone all considered periods only in its West-European cycle. In the other part of his study, E. Starostin proposed another variant of the periodization based on the criterion of information medium specifying the essential nature of archives. E. Starostin divided the Universal history of archives into four periods: the epoch of oral archives (from the origination of humankind to the IV-III millennium BC); the epoch of clay archives (the IV-III millennium BC), the epoch of paper archives (from the beginning of our era to the end of the XX century), and the epoch of electronic archives (the XXI century) ${ }^{8}$.

Both E. Starostin's concepts undergone to the critic in the book of a modern Russian scientist Tatjana Horhordina, who had been the best student of E. Starostin. She wrote: «When such periodization is applied, the extremely important nuance, particularly relating to peculiarities of the civilization process development on the Earth, disappears». T. Horhordina highlighted the fact that E. Starostin hadn't taken into consideration the existence of «oral archives» in the contemporary World. She protested against extracting the epoch of «clay archives» in a specific period. T. Horhordina noticed that in the Ancient World, apart from clay medium, people had used the wide range of other ones, notably, bamboo, silk and leather, stone, bark, etc. The archival collections were kept not only in monarchs' palaces but also in numerous public and private archives. In this regard, T. Horhordina wrote: «... apparently we should state the hopelessness of any scientific periodization of archives history according to types of information medium». The E. Starostin's periodization based on the functions of archives embarrassed T. Horhordina only in so far as it was a baffling task for her to make the choice in favour of any of the two proposed schemes 9 .

8 Cтаростин E. B. Методология истории архивов: периодизация // Отечественные архивы. 1999. № 6. С. 4-12; Его же. Зарубежное архивоведение. Москва: ИАИ РГГУ, 1997. 330 с.

9 Хорхордина Т. И. Российская наука об архивах. История. Теория. Люди. София, 2015. URL: https://electronic-library.org/books/Book_0062. html\#b0041 (дата обращения: 02.11.2020). 
E. Starostin perceived vulnerability and incompleteness of the theories proposed. Therefore, turning to the analysis of main functions of archives, he insisted on the necessity of isolating an investigated object as a whole, dividing it into components, and determining their levels of development and functional dependency. He proposed dividing the preservation function into such components: legal and normative acts which served as a basis for founding archives, sources of financing and budgets, the subordination of archives, characteristics of archival materials, the finding aids, staff, conditions of usage of archival documents. The function of usage, in E. Starostin's view, could have been divided into the presence of materials, accessibility and representativeness of sources, adequacy of methodology, etc. The ultimate aim, E. Starostin wrote, was to determine the development level of archives and archival methods, to identify the historical typology of archives, and to correlate them to a specific type of civilization. E. Starostin argued that the concept of the periodization proposed by him coincided marginally with the stages of human society development: «precapitalistic or preindustrial, capitalistic, industrial (western) and postmodern (postindustrial) information society». He feared somebody might say «he had been fascinated by so-called modernization theory» which he himself identified as "a narrow, one-sided, and built only on the basis of western material». E. Starostin insisted that the civilization theory, allocated 7, 13, 20 and more stable human civilizations, was the most prospective. He hoped his writings would encourage «new architects of the archival science to create more perfect theoretical constructions $\rangle^{10}$.

Irrespectively of E. Starostin's proposal, a conclusion about a data medium as one of the key criteria in the periodization of the Universal history of archives can be drawn. The fact that the realization of the function of documents' preservation was determined predominately by the information medium should not be ignored. The American scientist Ernst Posner in due time emphasized that the Mesopotamian archivists had realized the physical nature of a clay data media perfectly well. In the dry Mesopotamian climate, the clay tablets could have crumbled, and the texts written on them would have disappeared irretrievably. So the Mesopotamians often built the repositories underground or next to natural water supply sources or intentionally laid water-supply lines into archival buildings. For example, in the Eanna temple in Uruk the floor of the archival repositories looked like a system of low brick-built grooves parallel to each other thereby the water in furrows between them could flow and evaporate. Also, E. Posner stressed the fact that in the archives of Ancient Egypt (the period of the Old Kingdom) situated in the area flooded by the River Nile none of the

10 Старостин Е. В. Методология истории архивов... С. 4-12. 
papyrus survived ${ }^{11}$. And, of course, increased humidity is impermissible in the storages of paper documents. For instance, one of the grave threats to documents in the archives of Caribbean Basin countries is a natural humidity typical for tropical climate. The Caribbean Archives Association proposes assorted methods to fight against high humidity which causes the mould that devours historical documents. Latin American countries encounter a similar problem. In 2005 the Latin American Archive Association of the International Council on Archives published the Manual «Archival Building in a Tropical Climate and with Low Resources» which contains recommendations on constructing archival buildings in the equatorial zone. The authors of the Manual recommended locating repositories with paper documents inside buildings and surrounding them by other working accommodations and hallways. The thick walls can be the best tools for maintaining a stable level of temperature and humidity, and interior hallways will supply free air and prevent repositories from condensate ${ }^{12}$. Thus, the dependence of measures for providing the conditions for keeping documents on the physical nature of the data medium is an incontestable fact. Furthermore, every civilization found its data medium and elaborated intrinsic methods to store it.

Undoubtedly, different data media might be used by the same civilization. For example, the Ancient Romans used papyrus, linen and wood but, notably, a wooden tabula eventually became the typical data medium of textual information for the Roman civilization. Consequently, it is possible to determine the typical data medium for each civilization, even though this does not exclude the fact that several civilizations could use identical data medium (e. g., parchment or paper). Bearing in mind above-mentioned, the impossibility of excluding the criterion of data medium from the list of criteria, which the periodization of the Universal history of archives could have been based on, was concluded.

Although the confirmation on applying the civilization approach in the periodization of the Universal history of archives was obtained from the E. Starostin's studies, and his views on the use of the criterion of data medium as well as the approach to the periodization with the help of extracting the functions typical to archives were somewhat supported, the internal content of both functions cannot be agreed with. For example, the above-mentioned components of the preservation function don't reflect its essence and they are too far from reality. From the practical point of view, the preservation function should consists of such components as archival buildings, storage facilities and their equipment, climate-control (maintaining of the required level of temperature and humidity in repositories), security and fire protection

11 Posner Ernst. Archives in the Ancient World. Harvard University Press, Cambridge, Massachusetts, 1972. P. 54, 72.

12 Archive buildings in a tropical climate and with low resources. Paris, ICA, ALA, 2005. 44 p. 
regimes, differentiated access to storages and documents, restoration and conservation (or copying (rewriting) documents) with the aim of the retention period prolongation, safeguarding archives during natural and technological disasters as well as rescuing archives during wars and etc. If the list of preservation function components seems too modern, everyone might consult with N. Schneider, E. Posner, K. R. Veenhof and other scientists, who had already proved in their writings the presence of all these components in the archival practice of the Mesopotamian civilization. Thus, further revision and concretization of archival functions and their components, which can form the basis of the periodization, is required.

In addition to the preservation function such components as the existence of archival legislative (constitutions, statutes, regulations, and etc.), the organization of archival establishment work (staff, their level of education, distribution of duties, sources of financing and a budget), appraisal and evaluation (including approved retention schedules), acquisition, systematization and description of documents, finding aids preparation, and of course, searching and using of documents should be taken into consideration. Of equal importance is another component which should be named. It is the place and the significance of archives in the structure of bodies of power, and the attitude of the society towards archives. It reflects the level of attention, responsibility and protection that the authorities and the society manifest concerning archives and historical documents. This component is considered to indicate the «result» of the efforts of civilization in the field of saving and transferring information about itself to future generations. It might be measured in terms of quantity and quality of historical documents which the civilization had managed to save in archives and transfer to the next human generations.

Of course, a reciprocal influence of civilizations at each other is not excluded. For example, there is a sample of the Inka Empire. The Inkas recorded historical events, religious rituals, legislation, accounting and tax reports, statistical and genealogical data as well as literary works, songs etc. with the help of the khipu (quipu). The khipukamayuq were imperial officials responsible for making, reading and storing the khipus. The important fact was mentioned in «Discurso sobre la Descendencia y Gobierno de los Incas». The ruler of Peru Vaca de Castro wanted to obtain information about the origin of the Inka Empire, so he invited the oldest Incas to the palace to question them, but they could not say anything definite. Having realized they were in a difficult situation, they said that every previous ruler of the Inka Empire had had own khipukamayuq, but when Challcochima and Quisquis - captainsdespots of Ataovallpa Inga who ruined the Empire - seized power in Cusco, they killed many khipukamayuqs and burnt all their khipus stating that in such a way «they began a new world». The oldest Incas told Vaca de Castro about some khipukamayuqs - historians and book-keepers who hid out from 
despots in the mountains. According to «Discurso sobre la Descendencia y Gobierno de los Incas» the khipukamayuqs recorded all the events which happened during the governing of their kings as well as the events in the life of every Inca from his birth to death with the help of khipus. They were obliged to report on all the things that occurred truthfully and explain the significance of each thing to the rulers. The khipukamayuqs received the high income from the State Treasury as well as wives, concubines and servants. They taught their own children the profession and passed them their posts. The khipukamayuqs fulfilled their responsibilities very well and kept the khipus in good order. The khipukamayuqs who had survived in mountains arrived at Vaca de Castro and provided him with valuable information on the history of the Inca Empire. Their stories reached our time.

It is possible that there were khipu archives in monarchs' palaces, offices of civil and military servants, and even in private houses. For example, a tax archive was kept in the cacique Martin Cusi's house. When the Spaniards wanted to obtain information about Indians-payers of tribute, they asked him whether he had the report about taxpayers of Lurinsaya community among the khipus which were kept in his house. He submitted a wool cord with knots and said that it was the report on the Indians - tributaries of the whole province. Then, he was questioned about textiles and clothes manufactured in every town of the province, and about the Indians who worked in the mines. He submitted the khipus to the Spaniards one by one and reported detailed information on each issue based on the khipus from his archives ${ }^{13}$. When the Spaniards asked the Indians of village Xule about population size and the location their community, duties, properties and incomes of citizens, livestock, and so on; they answered that only a cacique and a khipukamayuq were able to provide this information because they were keepers of the khipus ${ }^{14}$.

Cristóbal de Molina wrote in 1916: «the Inka used a very subtle method of accounting of knotted strings of wool of different colors, which they call quipos; they could and did understand so much by this accounting device that they were able to give an accounting of all the things that had happened in this land for more than 500 years. They had Indians who were very skilled and knowledgeable in the quipos and accounts; these [Indians] passed the knowledge down from generation to generation; and fixing in the memory all that they learned, miraculously, nothing was forgotten $\rangle^{15}$. Thus, it could

13 Кипу в свидетельском показании главного касика дона Мартина Куси, 24 февраля 1567 года / Куприенко С. А. Источники XVI-XVII веков по истории инков: хроники, документы, письма. Киев, 2013. С. 219-220.

14 Заявление индейцев из Хули на обвинения предварительного следствия, 21 апреля 1567 года / Там же. С. 222-229.

15 Narrative Threads. Accounting and Recounting in Andean Khipu. Ed. by Jeffrey Quilter and Gary Urton. Austin, 2002. P. 9. 
be observed that the Inka had knipu archives and very qualified specialists the khipukamayuqs - keeping them. Gary Urton, the Professor from the Department of Anthropology (Harvard University) and the Head of Khipu Database Project (Khipu Archives), in his book «Inka History in Knots: Reading Khipus as Primary Sources» described khipu archives discovered during archaeological excavations ${ }^{16}$. In the article on khipu with accounting reports in Ancient Peru G. Urton implied the existence of duplicated khipu archives in all 80 provinces of the Inka Empire since he highlighted that «the governor of each province was required to keep a copy of khipu accounts so that «no deception could be practiced by either the Indian tribute payers or the official collectors $\rangle^{17}$. The Spaniards used the khipukamayuqs and khipu archives to obtain different information about the Incas. Unfortunately, the khipukamayuqs were not able to resist against the destruction of historical archives of the Inka Empire by the Spaniards. In his other book G. Urton quoted the following passage from Diego Avalos y Figueroa's Miscelánea Austral (1602): «In the valley of Xauxa, I met on the road an old Indian carrying a bundle of quipus, which he tried to hide. When challenged, he explained that these quipus were the account he had to give to the Inca [king], when he [the Inca] returned from the other world, of all that had happened in the valley in his absence. In the account were included all the Spaniards who had travelled on that royal road, what they had wanted and bought, and all they had done, both the good and the bad. The corregidor [high civil administrator] with whom I was travelling took and burned these accounts and punished the Indian». In the Third Council of Lima (15811583) the khipus were classified as idolatrous objects and were ordered to be burned ${ }^{18}$. Today most of the existing khipus originate from the Inka period (1400-1532 AD). There are approximately 1000 surviving khipus in museums and private collections around the World ${ }^{19}$. In addition to the fact that scientists only have a small amount of original khipus, they still cannot decipher these sources. It seems that the method of making them was lost forever.

The Maya codices found themselves in a similar situation. As indicated in the «Encyclopedia of the Ancient Maya»: «during the pre-Hispanic period screenfold books (called codices, codex in the singular) had incorporated

16 Urton Gary. Inka History in Knots, Reading Khipus as Primary Sources. Austin, 2017. 319 p.

17 Urton Gary, Bresine J. Carrie. Khipu Accounting in Ancient Peru. Science. Vol. 309. August 12, 2005. P. 1065.

18 Narrative Threads. Accounting and Recounting in Andean Khipu. Ed. by Jeffrey Quilter and Gary Urton. Austin, 2002. P. 10.

19 Khipu characteristics. [The electronic resource: «Khipu Database Project»] URL: http://khipukamayuq.fas.harvard.edu/WhatIsAKhipu.html (data of accession: 02.11.2020). 
knowledge about celestial cycles, agriculture, apiculture, and other topics... As the time of Spanish contact in the 1520s, dozens or hundreds of codices existed. Many were destroyed by Spanish friars and officials in their efforts to convert the Maya to Christianity, whereas a small number - three that are known today - were sent to Europe during the Colonial period, likely as «curiosities» or examples of the idolatrous practices of the native populations (Dresden, Madrid, and Paris codices) $\rangle^{20}$.

In analogical context, the fate of archives of the Byzantine Empire (3951453) can be considered. In the dissertation «The Archives of Byzantium, the $\mathrm{X}-\mathrm{XV}$ centuries» Alexander Menshikov proved that Byzantium could have been represented by not only the developed apparatus of state governance but also by the innumerable archives and libraries. A. Menshikov insisted on the fact that archives had already existed in the Byzantine Empire as a branch of state governance in its early days. A. Menshikov was able to find a few authentic sources about the organization of record-keeping practice and documents using in Byzantine church archives ${ }^{21}$. Unfortunately, today the historical heritage of Byzantium is scattered throughout different archives, libraries, museums and private collections, and only churches and monasteries can boast of the original Byzantine archives which survived up to nowadays ${ }^{22}$. The reason of such situation is well-known: the Byzantine Empire was plundered by the Latin crusaders and the Ottoman Turks, and only Christian churches and monasteries were saved untouched.

This short digression showed that frequently the conflict of civilizations had ruinous consequences. During these clashes the efforts applied by the outgoing civilizations to save their historical heritage did not matter. Not having any doubts in the legality of their actions, the representatives of stronger civilizations mercilessly and irretrievably had been destroying the historical sources of conquered civilizations. Today, scientists have been making incredible efforts to preserve the invaluable documentary sources of the past that came down to our days as well as to reconstruct the history of the civilizations which disappeared forever.

What could be considered embarrassing in the civilization theory? Its disadvantages were already mentioned by E. Starostin. The creators of civilization theory were not able to reach consensus on quantity

20 Witschey R. T. Walter. Encyclopedia of the Ancient Maya. Rowman \& Littlefield, 2015. P. 100.

21 Меньшиков А. В. Архивы Византии X-XV веков: дис. ... канд. ист. наук: 05.25.02 / Александр Владимирович Меньшиков; Историко-архивный институт Российского государственного гуманитарного университета. Москва, 2009. 156 с.

22 Меньшиков А. В. Из истории архивов Византийской церкви $\mathrm{X}-$ XV вв. // Отечественные архивы. Т. 4. Москва, 2005. С. 38-48. 
of civilizations. S. Huntington noticed that Carroll Quigley extracted $16^{23}$, Arnold Toynbee -21 or $23^{24}$, Oswald Spengler -8 (cultures) $^{25}$, William MacNeill $-9^{26}$, Philip Bagby $-9^{27}$, Fernand Braudel discussed 9 civiliza-

23 Quigley Carroll. The Evolution of Civilizations. An Introduction to Historical Analysis. Second edition. Indianapolis, 1979. P. 84; Idem. Tragedy and Hope: A History of the World in Our Time. New York, 1966. URL: https://archive. org/details/TragedyAndHope (data of accession: 02.11.2020).

Chapter 1 'Cultural Evolution in Civilizations'. Civilizations: Mesopotamian (6000-300 BC); Egyptian (5500-300 BC); Cretan (3500(3000)-1100(1000) BC; Indie (3500-1500 BC); Canaanite (2200-100 BC); Sinic (2000 BC-AD 400); Hittite (1900(1800) -1000 BC); Classical (1500(1100) BC-AD (500)600); Andean (1500 BC-AD 1600); Mayan (Mesoamerican) (1000 BC-AD 1550); Hindu (1800(1500) BC-AD 1900); Chinese (400-1930); Japanese (850(100) BC-1853(1950)); Islamic (600(500) BC-1750); Western (AD 400(500) to our days); Orthodox (350(600) our days).

24 Toynbee J. Arnold. A Study of History. Vol. I. Oxford University Press, 1948. P. 63-204, 239.

Civilizations: Orthodox Christian (Russia), Orthodox Christian (Byzantine, main body), Iranic and Arabic, Syriac, Jews, Indic, Sinic, Far Eastern (main body), Far Eastern (Korea and Japan), Western, Minoan, Sumeric, Hittite, Helenic (Greek and Roman), Hindu, Babylonic, Andean, Yucatec, Mexic, and Mayan, Egyptiac. A. Toynbee divided human societies into living societies and «fossil» societies. The basic idea of his conception consists of a cyclical development and a rotation of the successive local civilizations, which pass through analogical stages of development.

25 Spengler Oswald. The Decline of the West: Form and Actuality. T. 1. New York, 1926. 462 p.

Cultures such as Babylonian, Egyptian, Indic, Sinic, Mesoamerican (Mayan/ Aztec), Classical (Greek/Roman), Magian (Islamic), Western (European/American).

${ }^{26}$ MacNeill William. The Rise of the West: A History of the Human Community. Chicago, 2009. 860 p.

MacNeill didn't focus on the isolated development of one or another civilization. He emphasized interaction and mutual merger of different civilizations those, in his view, is a driving force of the historical process. The contacts between disparate participants of the historical process were not always positive for some of them because they often took place during military clashes. Nevertheless, during these contacts, diverse nations had acquired a large number of ideas and technologies that improved their life in the future. MacNeill concentrated his attention on processes due to which the majority of ideas and technologies moved from one nation to the other one. As a result, MacNeill glorified a triumph of West Europe that absorbed the achievements of preceded civilizations. Of course, some thinkers acknowledged the existence of non-European societies which could have been judged as «civilized» as well.

27 Bagby Philip. Culture and History: Prolegomena to the Comparative Study of Civilizations. London, 1958. 224 p.

Philip Bagby insisted on 12 civilizations, in the case of isolating the Japanese civilization from the Chinese one, and separating the Orthodox civilization from the Western one. 
ions $^{28}$, and Matthew Melko named 1229. Finally, Samuel Huntington identified the major contemporary civilizations summarizing opinions of his predecessors (Sinic, Japanese, Hindu, Islamic, Western, Latin American, African $)^{30}$.

S. Huntington wrote that «human history is the history of civilization». $\mathrm{He}$ agreed that a distinction exists between civilization «in the singular» and civilizations «in the plural». French authors elaborated a concept of civilization to identify the European civilization as «civilized» and others as «uncivilized» or barbarian societies. In their opinion, European civilization was civilization «in the singular». Of course, some thinkers acknowledged the existence of non-European societies which could have been judged as «civilized» as well. S. Huntington stated that there were many civilizations, and each of them was civilized in its own way. The idea of civilization «in the singular» was considered by him in the term of «the universal world civilization». Here he referred to Viviadhar Naipaul who had united the modern civilizations into one and called it «the universal civilization».

For Braudel, Wallerstein ${ }^{31}$, Dawson ${ }^{32}$, Spengler ${ }^{33}$, and others, civilization was a cultural phenomenon. Other authors correlated the concept of civilization with a concept of the human race. S. Huntington, in contrast, considers different elements including blood ties, language, and lifestyle; interestingly, he posited that religion was the most important element. «People of the same race can be deeply divided by civilization;

28 Braudel Fernand. History of Civilizations. New York, 1994. 640 p.; Idem. On History. Chicago, 1980. 226 p.

29 Melko Matthew. Nature of Civilizations. Boston, 1969. 204 p.

Matthew Melko named 12 civilizations, among them seven had already disappeared (Mesopotamian, Egyptian, Cretan, Classical, Byzantine, Central American, Andean), and five have still existed (Chinese, Japanese, Hindu, Islamic and Western).

30 Huntington P. Samuel. The Clash of Civilizations and the Remaking of World Order. Simon and Schuster, 1996. P. 40-48.

31 Wallerstein Immanuel. World-System Analysis. Duke University Press, 2004. 128 p.; Idem. The Modern World-System I: Capitalist Agriculture and the Origins of the European World-Economy in the Sixteenth Century. Academic Press, 1974. 440 p.; Idem. The Modern World-System II: Mercantilism and the Consolidation of the European World-Economy, 1600-1750. University of California Press, 1980. 397 p.; Idem. The Modern World-System III: The Second Era of Great Expansion of the Capitalist World-Economy, 1730-1840s. University of California Press, 1989. 372 p.; Idem. Utopistics: Or, Historical Choices of the Twenty-First Century. New York: W. W. Norton \& Company, Inc., 1998. 93 p.

32 Dawson Christopher. Religion and the Rise of Western Culture: The Classic Study of Medieval Civilization. 1991. 244 p.; Idem. Dynamics of World History. Intercollegiate Studies Institute, 2002. 512 p.

33 Spengler Oswald. The Decline of the West. Vol. I. 2013. 462 p.; Vol. II. 2013. $554 \mathrm{p}$. 
people of different races may be united by civilization. In particular, the great missionary religions, Christianity and Islam, encompass societies from a variety of races. The crucial distinctions among human groups concern their values, beliefs, institutions, and social structures, not their physical size, head shapes, and skin colors», - wrote S. Huntington. For him «civilizations are comprehensive, that is, none of their constituent units can be fully understood without reference to the encompassing civilization. Simultaneously, civilization is a «totally». S. Huntington quoted Melko who had said that «Civilizations have a certain degree of integration. Their parts are defined by their relationship to each other and to the whole. If civilization is composed of states, these states will have more relation to one another than they do to states outside the civilization. They might fight more, and engage more frequently in diplomatic relations. They will be more interdependent economically. There will be pervading aesthetic and philosophical currents». S. Huntington stated: «civilizations are mortal but also very long-lived; they evolve, adapt, and are the most enduring of human association», «civilizations have no clear-cut boundaries and no precise beginnings and endings». Moreover, he agreed with Bagby and Toynbee who had suggested dividing civilizations into major and peripheral or major and abortive. The political composition of civilizations can vary. A civilization may, according to S. Huntington, contain one or many political units. «Those units may be city states, empires, federations, confederations, nation states, multinational states, all of which may have varying forms of government. As a civilization evolves, changes normally occur in the number and nature of its constituent political units. At one extreme, a civilization and a political entity may coincide». Finally, he proposed a definition of civilization that states: «the highest cultural grouping of people and the broadest level of cultural identity people have short of that which distinguishes humans from other species. It is defined both by common objective elements, such as language, history, religion, customs, institutions, and by the subjective selfidentification of people $»^{34}$.

By adopting the civilization approach to construct the periodization of the Universal history of archives, the scholars would evade the necessity of building generalized linear models with hard links between components. Since every civilization is a unique, autonomous, self-sufficient, and internally comprehensive system, it is possible to arrange civilizations horizontally (undoubtedly, with the focus of shift). It is admissible to supply new or overlooked elements to the existing arrangement. Factually, such periodization will look like a set of different self-sufficient components. Thus, the disadvantages mentioned by E. Starostin can be transformed to become the advantages.

${ }^{34}$ Huntington P. Samuel. The Clash of Civilizations and the Remaking of World Order. Simon and Schuster, 1996. P. 40-48. 
Taking into account that every civilization corresponds to its intrinsic information medium, general periodization of the Universal history of archives can be represented as shown in Table 1.

Table 1

\begin{tabular}{|c|c|c|}
\hline Civilizations & Characteristics & Results \\
\hline 1 & 2 & 3 \\
\hline $\begin{array}{l}\text { Mesopotamian } \\
\text { civilization - } \\
\text { "the epoch of } \\
\text { clay tablets" } \\
(6000-300 \mathrm{BC})\end{array}$ & $\begin{array}{l}\text { To a great extent, due to the } \\
\text { data medium - clay tablets } \\
\text { and specific methods for their } \\
\text { storing - the archives of the } \\
\text { Mesopotamian civilization } \\
\text { survived almost } 5 \text { thousand } \\
\text { years and came down to } \\
\text { nowadays. }\end{array}$ & $\begin{array}{l}\text { Scientists discovered } \\
\text { approximately } 20000 \text { clay } \\
\text { tablets in the archives of } \\
\text { ancient Ebla; there are almost } \\
100000 \text { clay tablets with the } \\
\text { economic texts in the archives } \\
\text { of the III dynasty of Ur; the } \\
\text { archives of Mari gave more } \\
\text { than } 20000 \text { clay tablets; the } \\
\text { archives of the Hittite Empire } \\
\text { represents more than } 30000 \\
\text { clay tablets }{ }^{35} \text {. This list of } \\
\text { archives can be continued. }\end{array}$ \\
\hline $\begin{array}{l}\text { Egyptian } \\
\text { civilization - } \\
\text { "the epoch } \\
\text { of papyrus" } \\
(5500-300 \mathrm{BC})\end{array}$ & $\begin{array}{l}\text { The Egyptian civilization } \\
\text { developed simultaneously with } \\
\text { the Mesopotamian. For Egypt, } \\
\text { the most typical information } \\
\text { medium was papyrus. The } \\
\text { Egyptian bureaucratic system } \\
\text { produced a large number of } \\
\text { documents and could have } \\
\text { left behind enormous archives } \\
\text { the bigger ones than the } \\
\text { Mesopotamian civilization. } \\
\text { Should not be underestimated } \\
\text { the physical properties } \\
\text { of papyrus, however, the } \\
\text { quantity of documents which } \\
\text { reached till our time is far less } \\
\text { considerable }{ }^{36} \text {. }\end{array}$ & $\begin{array}{l}\text { The Italian researcher Orsolina } \\
\text { Montevecchi, in her work «La } \\
\text { papirologia» counted only } \\
135 \text { papyrus archives and this } \\
\text { is for more than } 4,5 \text { thousand } \\
\text { years of the existence of the } \\
\text { Egyptian civilization }{ }^{37} \text {. } \\
\text { It means that both the data } \\
\text { medium and the methods of } \\
\text { storing used by the Egyptians } \\
\text { were not satisfactory. }\end{array}$ \\
\hline
\end{tabular}

35 «Cuneiform Archives and Libraries». Papers read at the $30^{\text {th }}$ Rencontre Assyriologique Internationale, Leiden, 4-8 July 1983. Nederlands Instituut voor het Nabije Oosten, Leiden, 1986. Ed. by Klaas R. Veenhof. 307 p.

36 Posner Ernst. Archives in the Ancient World. Harvard University Press, Cambridge, Massachusetts, 1972. P. 71-90.

37 Montevecchi Orsolina. La papirologia. Vita e Pensiero, 1988. 804 p.; Fournet Jean-Lue. Archives and Libraries in Greco-Roman Egypt / Sabine Kienitz, Michael Friedrich, Christian Brockmann \& Alessandro Bausi (Eds.). Manuscripts and Archives: Comparative Views on Record-Keeping. De Gruyter. 2018. P. 171200. DOI: 10.1515/9783110541397-006. 
Продовж. таблиизі

\begin{tabular}{|c|c|c|}
\hline 1 & 2 & 3 \\
\hline & $\begin{array}{l}\text { Also, Egyptian civilization } \\
\text { absorbed influences from the } \\
\text { Mesopotamian civilization. } \\
\text { For instance, the Tel-el- } \\
\text { Amarna archives kept } \\
\text { diplomatic correspondence of } \\
\text { the Egyptian pharaohs in the } \\
\text { clay tablets. }\end{array}$ & \\
\hline $\begin{array}{l}\text { Greco-Roman } \\
\text { (classical) } \\
\text { civilization - } \\
\text { "the epoch of } \\
\text { wooden tabula» } \\
(1500(1100) \\
\text { BC }-(500) 600 \\
\text { AD) }\end{array}$ & $\begin{array}{l}\text { The data media used by this } \\
\text { civilization are different: } \\
\text { papyrus, linen or «Libri lintei», } \\
\text { lead plates, wax or gypsum } \\
\text { covered wooden tablets and } \\
\text { codices, parchment. It is } \\
\text { also appropriate to mention } \\
\text { the so-called lapidary } \\
\text { archives - collections of short } \\
\text { inscriptions carved stones. } \\
\text { The earliest Roman linen } \\
\text { documents were kept in the } \\
\text { archives of the goddess Juno } \\
\text { Moneta temple. Most Roman } \\
\text { archives of the Republican } \\
\text { period kept the documents } \\
\text { on wooden media: Aerarium, } \\
\text { the plebeian archives of } \\
\text { the temple of Ceres, Liber } \\
\text { and Libera, the archives of } \\
\text { censors located in the temple } \\
\text { of Nymph on the Champ de } \\
\text { Mars, the archives of equities } \\
\text { in the temple of goddess } \\
\text { Libertas, the diplomatic } \\
\text { archives in the temple of } \\
\text { goddess Fides, the archives } \\
\text { of the Board of Pontiffs and } \\
\text { Tabularium built by Quintus } \\
\text { Lutatius in } 79 \text { BC. In the } \\
\text { imperial period, the Imperial } \\
\text { archives kept the Roman } \\
\text { emperors' documents. } \\
\text { On this subject E. Posner } \\
\text { has written: «... for in Rome }\end{array}$ & $\begin{array}{l}\text { Ernst Posner implied at least } \\
\text { two cases of documents } \\
\text { burning. An ancient sculptor } \\
\text { depicted the first of them on } \\
\text { the marble relief «Anaglypha } \\
\text { Trajani» in Curia Iulia. The } \\
\text { relief shows military people } \\
\text { bringing bundles of wooden } \\
\text { tabulas and dumping them in } \\
\text { two piles which are about to } \\
\text { be engulfed in the sacrificial } \\
\text { flames. Secondly, the wooden } \\
\text { documents appeared to be } \\
\text { at hand in } 52 \text { BC when a } \\
\text { crowd of the Romans brought } \\
\text { the body of dead patrician } \\
\text { Publius Claudius Pulcher } \\
\text { to the Forum and burnt it } \\
\text { directly in the Senate building } \\
\text { using benches, chairs, tables, } \\
\text { and documents. } \\
\text { Regarding wooden medium } \\
\text { used in Republican Rome, } \\
\text { E. Posner said: «Even if } \\
\text { not purposely used as fuel, } \\
\text { wood tablets could not be } \\
\text { expected to last; hence only } \\
\text { a few examples of them } \\
\text { have come down to us». } \\
\text { Two thousand years later, } \\
\text { the Roman archives are } \\
\text { empty and destroyed almost } \\
\text { completely } 38 \text {. }\end{array}$ \\
\hline
\end{tabular}

38 Posner Ernst. Archives in the Ancient World. Harvard University Press, Cambridge, Massachusetts, 1972. P. 162. 
Продовж. таблиц̧і

\begin{tabular}{|c|c|c|}
\hline 1 & 2 & 3 \\
\hline & $\begin{array}{l}\text { record-making as a relatively } \\
\text { original and national } \\
\text { phenomenon was already fully } \\
\text { developed when papyrus, the } \\
\text { preferred writing material of } \\
\text { the East, became available. } \\
\text { Instead, the wood tablet } \\
\text { (tabula) remained in use, and } \\
\text { the Romans stuck to it with } \\
\text { truly Roman tenacity, because, } \\
\text { although inconvenient, it had } \\
\text { its advantages, if only that } \\
\text { wood was cheap and easily } \\
\text { obtainable in Italy }{ }^{39} \text {. }\end{array}$ & \\
\hline $\begin{array}{l}\text { Indus Valley } \\
\text { (Harappan) } \\
\text { civilization - } \\
\text { "the epoch of } \\
\text { steatite data } \\
\text { medium" } \\
3700-1300 \mathrm{BC} \text { ) }\end{array}$ & $\begin{array}{l}\text { The ancient Harappans left } \\
\text { us more than } 3500 \text { short } \\
\text { inscriptions discovered at } \\
\text { the archaeological sites in } \\
\text { India }{ }^{40} \text {. Except them, there } \\
\text { are } 2138 \text { objects belonging } \\
\text { to collections in Pakistan. } \\
\text { Almost all these inscriptions } \\
\text { were found on the seals } \\
\text { which served not only for } \\
\text { administrative and economic } \\
\text { goals but also as tokens of } \\
\text { votive offerings or of visits } \\
\text { to temples }{ }^{4} \text {. The seals and } \\
\text { tablets were made from } \\
\text { different materials: terracotta, } \\
\text { ceramic, stoneware, glazed } \\
\text { faience; shell, bone, ivory; } \\
\text { sandstone, steatite (soapstone); }\end{array}$ & $\begin{array}{l}\text { Unfortunately, all the } \\
\text { attempts at deciphering the } \\
\text { unknown writing system } \\
\text { appeared till nowadays were } \\
\text { unsuccessful. There are no } \\
\text { ideas to understand historical } \\
\text { texts, call the names of the } \\
\text { Harappan gods, kings or } \\
\text { cities. The scientists have } \\
\text { been debating the type of the } \\
\text { writing system represented } \\
\text { by the Indus script. All the } \\
\text { texts are short and limited in } \\
\text { nature: the average length is } \\
\text { five signs, and the two longest } \\
\text { texts contain } 26 \text { signs each }{ }^{42} \text {. } \\
\text { Thus, in this situation, we } \\
\text { cannot say anything about } \\
\text { archives at all. }\end{array}$ \\
\hline
\end{tabular}

39 Ibid. P. 160-224.

40 Corpus of Indus Seals and Inscriptions. Ed. by Jagat Pati Joshi \& Asko Parpola. Vol. 1. Collections in India. Helsinki: Suomalainen Tiedeakatemia, 1987. P. XVII.

${ }^{41}$ Corpus of Indus Seals and Inscriptions. Ed. by Sayid Ghulam Mustafa Shan \& Asko Parpola. Vol. 2. Collections in Pakistan. Helsinki: Suomalainen Tiedeakatemia, 1991. P. VII, XXII.

${ }^{42}$ Corpus of Indus Seals and Inscriptions. Ed. by Jagat Pati Joshi \& Asko Parpola. Vol. 1. ... P. XVIII; Possehl L. Gregory. The Indus Civilization. A Contemporary Perspective. AltaMira Press, 2002. P. 130-136. 


\begin{tabular}{|c|c|c|}
\hline \multirow[t]{2}{*}{1} & 2 & 3 \\
\hline & $\begin{array}{l}\text { gypsum; copper and copper } \\
\text { alloys, silver and gold }{ }^{43} \text {. The } \\
\text { preferable data medium was } \\
\text { steatite }^{44} \text {. }\end{array}$ & \\
\hline $\begin{array}{l}\text { Ancient Chinese } \\
\text { civilization } \\
\text { (including } \\
\text { cultures of Hong } \\
\text { Kong, Taiwan, } \\
\text { Singapore, } \\
\text { Korea, a } \\
\text { Vietnam relating } \\
\text { to it) - "the } \\
\text { epoch of } \\
\text { bamboo slips» } \\
\text { (2000 BC - } \\
400 \text { AD) }\end{array}$ & $\begin{array}{l}\text { The ancient Chinese wrote on } \\
\text { the wooden or bamboo slips } \\
\text { and silk scrolls. In the III-IV } \\
\text { centuries, these materials were } \\
\text { displaced almost completely } \\
\text { by paper. } \\
\text { The first expeditions in the } \\
\text { desert ruins dated by the } \\
\text { beginning of the XX century } \\
\text { gave such results: Aurel } \\
\text { Stein discovered around one } \\
\text { thousand bamboo and wooden } \\
\text { slips from Han to Tang } \\
\text { times; Sven Hedin and Folke } \\
\text { Bergman - around } 10000 \\
\text { pieces. The reconstruction } \\
\text { of early bamboo and wood } \\
\text { manuscripts started with these } \\
\text { major discoveries }{ }^{45} \text {. } \\
\text { Also, the archaeologists } \\
\text { discovered the huge archive } \\
\text { with the more than } 150 \\
\text { thousand pictographic records }\end{array}$ & $\begin{array}{l}\text { It was specific for China to } \\
\text { eliminate the memory about } \\
\text { predecessors. For example, Ye } \\
\text { Wa and Joseph W. Esherick } \\
\text { noticed: «it was the usual } \\
\text { practice of Chinese rulers to } \\
\text { destroy any surviving records } \\
\text { of the previous dynasty after } \\
\text { its official dynastic history } \\
\text { had been compiled... we } \\
\text { lack systematic archival } \\
\text { records prior to the Qing. } \\
\text { But Chinese rulers were not } \\
\text { only anxious to eliminate the } \\
\text { records of previous dynasties } \\
\text { after they had compiled the } \\
\text { official history through which } \\
\text { their predecessors were to be } \\
\text { known. They also regularly } \\
\text { destroyed the routine } \\
\text { records of earlier reigns of } \\
\text { their own dynasty after the } \\
\text { Veritable Records }{ }^{46} \text { had been } \\
\text { compiled» }{ }^{47} \text {. }\end{array}$ \\
\hline
\end{tabular}

43 Corpus of Indus Seals and Inscriptions. Ed. Asko Parpola, B. M. Pande, Petteri Koskikallio. Vol. 3. New materials, untraced objects, and collections outside India and Pakistan. Helsinki: Suomalainen Tiedeakatemia, 2010. P. XLVIII.

44 Альбедиль М. Ф. Протоиндийская цивилизация: очерки культуры. Москва: Восточная литература, 1994. С. 87, 136, 156.

45 Staack Thies. Reconstruction of Early Chinese Bamboo and Wood Manuscripts: A Review (1900-2010). University Hamburg: Centre for the study of manuscript cultures. 2016, April. URL: http://www.manuscript-cultures.unihamburg.de/papers_e.html (data of accession: 02.11.2020).

46 Veritable Records are historical texts written by official historians of Chinese dynasties since the 6th century, and also in Korea, Japan and Vietnam. Usually, such records were to be compiled immediately after a monarch died. They contain a large amount of political, economic, military, and biographical information dated the period of monarch's ruling.

$47 \mathrm{Wa}$ Ye \& Esherick Joseph W. Chinese Archives. An Introductory Guide. Institute of East Asian Studies University of California. Berkeley, 1996. P. 5, 6. 


\begin{tabular}{|c|c|c|}
\hline 1 & 2 & 3 \\
\hline & $\begin{array}{l}\text { on blade bones of cattle and } \\
\text { turtle shells. Most ancient } \\
\text { records originated from the } \\
\text { Imperial ritual archives of } \\
\text { the Shang (1600-1046 BC), } \\
\text { archives of Zhou (1046-256 } \\
\text { BC), Qin (221-206 BC), Han } \\
\text { (206 BC - } 9 \text { AD), and other } \\
\text { dynasties }{ }^{48} \text {. } \\
\text { Some of the first silk } \\
\text { manuscripts were uncovered } \\
\text { at Han tombs at Mawangdui: } \\
\text { archaeologists found around } \\
40 \text { books with } 100000 \text { words } \\
\text { there }{ }^{49} \text {. Unfortunately, silk } \\
\text { was very expensive and } \\
\text { from this reason, it didn't } \\
\text { gain widespread shares as a } \\
\text { material for writing. } \\
\text { The main data medium in } \\
\text { Ancient China was bamboo } \\
\text { slips. For example, this fact } \\
\text { can be proved by findings of } \\
\text { more than } 140000 \text { bamboo } \\
\text { and wooden slips of the } \\
\text { Three Kingdoms (220-280 } \\
\text { AD) which were uncovered at } \\
\text { Zoumalou (Hunan province) } \\
\text { in October } 1996 \text { It was } \\
\text { highlighted that this single } \\
\text { major find exceeded the sum } \\
\text { total of all the bamboo slips } \\
\text { that had previously come to } \\
\text { light. The huge collection } \\
\text { consisting of more than } 10000 \\
\text { bamboo slips and deriving } \\
\text { from the Warring States }\end{array}$ & \\
\hline
\end{tabular}

48 Folster Max Jakob. Library and Archives in the Former Han Dynasty (206 DCE - 9 CE): Arguing for a Distinction. Bausi, Alessandro; Brockmann, Christian; Friedrich, Michael; Kienitz, Sabine (eds.): Manuscripts and Archives: Comparative Views on Record-Keeping. (Studies in Manuscript Cultures 11). Berlin: de Gruyter, 2018. P. 201-230.

49 The Treasure on Silk and Inscribed Slips. Hunan Provincial Museum. URL: https://web.archive.org/web/20160704032000/http://www.hnmuseum.com/ hnmuseum/eng/whatson/exhibition/mwd_2_5.jsp (data of accession: 02.11.2020). 
Продовж. таблиці

\begin{tabular}{|c|c|c|}
\hline 1 & 2 & 3 \\
\hline & $\begin{array}{l}\text { period (476-221 BC) was } \\
\text { unearthed at Liye village } \\
\text { (Hunan province as well) at } \\
\text { the beginning of } 2000 \text { s. In the } \\
\text { same region, archaeologists } \\
\text { unearthed the } 20000 \text { bamboo } \\
\text { slips concerning the Qin } \\
\text { Dynasty and identified as } \\
\text { official documents }{ }^{50} \text {. }\end{array}$ & \\
\hline $\begin{array}{l}\text { Mesoamerican } \\
\text { civilization (the } \\
\text { Olmecs, Mayas, } \\
\text { Aztecs etc.) - } \\
\text { "the epoch of } \\
\text { Amate» (1000 } \\
\text { BC - } 1550 \text { AD) }\end{array}$ & $\begin{array}{l}\text { Documents were being created } \\
\text { in huge quantities in all } \\
\text { spheres of the pre-Columbian } \\
\text { society and preserved in } \\
\text { archives of Mesoamerica. } \\
\text { Michael Arbagi stressed the } \\
\text { civilizations of Mesoamerica } \\
\text { wrote documents in picture } \\
\text { glyphs or hieroglyphic system, } \\
\text { writers kept these documents } \\
\text { on scrolls or screen-fold books } \\
\text { on a form of paper that they } \\
\text { made from animals skin (deer, } \\
\text { jaguar, manatee) or the bark } \\
\text { of trees. The principal kind } \\
\text { of data media was Amate - } \\
\text { paper made from the trees of } \\
\text { the fig family }{ }^{51} \text {. }\end{array}$ & $\begin{array}{l}\text { Michael Arbagi noticed } \\
\text { that the Spanish conquerors } \\
\text { acknowledged Mesoamerican } \\
\text { societies» } \\
\text { achievements. In the same } \\
\text { time he said that the Spanish } \\
\text { invaders and Catholic clergy } \\
\text { destroyed many of the old } \\
\text { documents and archives of the } \\
\text { civilizations which preceded } \\
\text { them }{ }^{52} \text {. Today it is difficult } \\
\text { to estimate the amount of lost } \\
\text { forever manuscripts. }\end{array}$ \\
\hline $\begin{array}{l}\text { Andean } \\
\text { civilization (the } \\
\text { oldest of them - } \\
\text { Norte Chico } \\
\text { civilization, }\end{array}$ & $\begin{array}{l}\text { Only two khipu archives were } \\
\text { found together: Chachapoyas } \\
\text { archive discovered at the north } \\
\text { of Peru and the khipu archive } \\
\text { of Puruchuto on the coast near } \\
\text { Lima. Other archives - Ica, }\end{array}$ & $\begin{array}{l}\text { In } 1532 \text { the Inca Empire was } \\
\text { conquered by the Spanish } \\
\text { conquistadors. The Neo-Inca } \\
\text { State lasted until } 1572 \text {. Almost } \\
\text { all khipus were destroyed. } \\
\text { Although, the Incas have been }\end{array}$ \\
\hline
\end{tabular}

50 The Age of the Bamboo Slip. URL: http://www.china.org.cn/english/2003/ Jun/66332.htm\#: : text=16th\%2D11 th\%20centuries\%20BC)\%20and\%20Zhou\%20 Dynasty $\% 20$ (c.\&text $=$ However $\% 20$ from $\% 20$ the $\% 20$ Shang $\% 20$ and,Age $\% 20$ of $\% 20$ the $\% 20$ Bamboo\%20Slip (data of accession: 02.11.2020).

51 Citlalli López Binnqüist Rosaura. The endurance of Mexican Amate paper: exploring additional dimensions to the sustainable development concept. Dissertation to obtain the doctor's degree at the University of Twente. Mexico, 2003. 344 p.

52 Arbagi Michael. The Catholic Church and the preservation of Mesoamerican archives: an assessment // Archival Issues. Vol. 33. № 2. 2011. P. 112-120. 


\begin{tabular}{|c|c|c|}
\hline 1 & 2 & 3 \\
\hline $\begin{array}{l}3700 \mathrm{BC}-1800 \\
\mathrm{BC}-\text { - } t \text { the } \\
\text { epoch of khipu» }\end{array}$ & $\begin{array}{l}\text { Circum-Ica and Pachacmac - } \\
\text { were formed in the way of } \\
\text { the grouping of different } \\
\text { collections of khipus. In } \\
\text { generally there are more } \\
\text { than one thousand khipus } \\
\text { in museums and private } \\
\text { collections around the World. } \\
\text { Most khipus originated from } \\
\text { the period of the Inca Empire } \\
(1400-1532)^{53} \text {. }\end{array}$ & $\begin{array}{l}\text { using khipus until present } \\
\text { days but the more ritual than } \\
\text { practical purposes. }\end{array}$ \\
\hline $\begin{array}{l}\text { Byzantine } \\
\text { civilization - } \\
\text { "the epoch } \\
\text { of tanned } \\
\text { parchment» } \\
(395-1453)\end{array}$ & $\begin{array}{l}\text { The bureaucratic apparatus } \\
\text { of the Byzantine Empire } \\
\text { created a lot of documents } \\
\text { in the public administration, } \\
\text { legal (in courts, notaries etc.), } \\
\text { economic and private spheres. } \\
\text { It should not be forgotten } \\
\text { that Byzantium being the } \\
\text { first Christian empire and the } \\
\text { most highly developed state } \\
\text { of that time accumulated } \\
\text { the intellectual elite from all } \\
\text { over the world, preserved } \\
\text { the heritage of classical } \\
\text { civilization, multiplied } \\
\text { treatises and theological } \\
\text { literature. The principal data } \\
\text { medium in Byzantium was } \\
\text { parchment. Unfortunately, } \\
\text { the formula for its production } \\
\text { wasn't preserved, and } \\
\text { the secret of parchment } \\
\text { manufacturing is unclear for } \\
\text { modern researchers. Its texture } \\
\text { more closely resembles tanned } \\
\text { hide. For a little while (the } \\
\text { middle XI - the middle XIII } \\
\text { centuries), Byzantines used the } \\
\text { paper, but it was recognized a } \\
\text { poor-quality material, so the } \\
\text { Byzantine Empire was back to } \\
\text { the parchment. }\end{array}$ & $\begin{array}{l}\text { In the doctoral thesis on «The } \\
\text { Archives of Byzantium of the } \\
\text { X-XV centuries» Alexander } \\
\text { Menshikov said that there is } \\
\text { quite convincing evidence of } \\
\text { the existence in the Byzantine } \\
\text { Empire of numerous and } \\
\text { developed archives and } \\
\text { libraries. But in reality, } \\
\text { the Byzantine civilization } \\
\text { bequeathed us only archives } \\
\text { and libraries had stored in } \\
\text { monasteries and churches. } \\
\text { Most Byzantine vaults were } \\
\text { looted or destroyed during the } \\
\text { Crusades, in wars with the } \\
\text { Persians, Arabs and Turks }{ }^{54} \text {. }\end{array}$ \\
\hline
\end{tabular}

53 What are Khipu Archives? Khipu Database Project. URL: https:// khipukamayuq.fas.harvard.edu/Khipu-Archives.html (data of accession: 02.11.2020).

54 Меньшиков А. В. Архивы Византии X-XV веков... Указ. соч. 
Продовж. таблиці

\begin{tabular}{|c|c|c|}
\hline 1 & 2 & 3 \\
\hline $\begin{array}{l}\text { Northwest } \\
\text { Old World } \\
\text { Civilization } \\
\text { (Western, } \\
\text { Orthodox and } \\
\text { Islamic) - «the } \\
\text { epoch of paper } \\
\text { data media» } \\
\text { (from Christmas } \\
\text { till the end of } \\
\text { XX centuries) }\end{array}$ & $\begin{array}{l}\text { David Wilkinson insisted } \\
\text { that there is a single } \\
\text { central civilization which } \\
\text { incorporated three civilizations } \\
\text { of the Old World preceded } \\
\text { the modern civilization. All } \\
\text { of them had used different } \\
\text { nature information media and } \\
\text { afterwards made the transition } \\
\text { from parchment, which was } \\
\text { more sustainable material, to } \\
\text { the perishable paper medium } 5 \text {. } \\
\text { We cannot accept the idea } \\
\text { of dating the Northwest Old } \\
\text { World Civilization proposed } \\
\text { by David Wilkinson (1500 } \\
\text { BC until Present). But we also } \\
\text { cannot deny that for Western, } \\
\text { Orthodox and Islamic } \\
\text { civilizations was typical } \\
\text { the same information data } \\
\text { medium. These civilizations } \\
\text { can distinct from each other by } \\
\text { religion, customs, languages } \\
\text { etc. Yet, they used paper as } \\
\text { the main data medium during } \\
\text { the long run of their history. }\end{array}$ & $\begin{array}{l}\text { Despite wars, revolutions, } \\
\text { natural catastrophes, } \\
\text { decisions of authorities, these } \\
\text { civilizations have managed } \\
\text { to preserve a large enough } \\
\text { number of documents created } \\
\text { by them. Yet, conscious of } \\
\text { the quality of the information } \\
\text { data medium we are not } \\
\text { able to predict their survival } \\
\text { during the same continuous } \\
\text { period which the clay tablets } \\
\text { had overcome. }\end{array}$ \\
\hline $\begin{array}{l}\text { Modern } \\
\text { civilization - } \\
\text { "the epoch of } \\
\text { digital data } \\
\text { medium" }\end{array}$ & $\begin{array}{l}\text { The digital data media } \\
\text { depends on the energy } \\
\text { sources, rapid changing of } \\
\text { hardware and software, and } \\
\text { the global problem is we are } \\
\text { not able to extract from and } \\
\text { read no information from } \\
\text { data medium without special } \\
\text { equipment and computer } \\
\text { programs. The recorded on } \\
\text { our data medium information } \\
\text { isn't perceived by the human } \\
\text { eye. Just coming-to-be our } \\
\text { civilization has already lost a } \\
\text { large amount of data. }\end{array}$ & $\begin{array}{l}\text { In future, it is expected that } \\
\text { the Modern civilization } \\
\text { would bequeath to the next } \\
\text { generation no historical } \\
\text { documents created by itself. }\end{array}$ \\
\hline
\end{tabular}

55 Wilkinson David. Central Civilization // Comparative Civilizations Review: 17(17), Art. 4. 1987. URL: https://scholarsarchive.byu.edu/ccr/vol17/iss17/4 (data of accession: 02.11.2020). 
Thus, 10 civilizations including the modern one were selected based on the analysis of the civilizationists' works and taken into consideration in this study. The specific information data medium was identified for each of them. As the result, the following periodization was created:

- «the epoch of clay tablets» - Mesopotamian civilization (6000 $300 \mathrm{BC})$;

- «the epoch of papyrus» - Egyptian civilization (5500 - 300 BC);

- «the epoch of wooden tabula» - Greco-Roman (classical) civilization (1500(1100) BC - (500)600 AD);

- «the epoch of steatite tablets» - Indus Valley (Harappan) civilization $(3700-1300$ BC);

- «the epoch of bamboo slips» - Ancient Chinese civilization (2000 $\mathrm{BC}-400 \mathrm{AD})$;

- «the epoch of Amate» - Mesoamerican civilization (1000 BC 1550 AD);

- «the epoch of khipu» - Andean civilization (3700 BC - 1800 BC);

- «the epoch of tanned parchment» - Byzantine civilization (3951453);

- «the epoch of paper» - Northwest Old World Civilization (Western, Orthodox and Islamic) (from Christmas till the end of XX centuries);

- «the epoch of digital data medium» - Modern civilization (the XXI century and going).

Such a sample of periodization does not require the accommodation of elements in strict sequence. Therefore, it is more beneficial than the linear (rising) periodization as different civilizations existed simultaneously. Scholars can integrate more civilizations in the horizontal schema or separate them into subgroups without difficulty. Moreover, experts can determine the characteristics of methods which each civilization employed to preserve their archives. Undoubtedly, each information data medium demanded specific terms of storage. This question was overlooked to avoid straying from the core topic. Sometimes civilizations, e. g. China, destroyed their historical heritage voluntarily. In other cases, a civilization loses its archives as a result of the clash with another civilization. Nevertheless, in general, the archives are often taken away by the implacable brutality of the time. In this context, the nature of the information data medium plays a decisive role. Tragically, the ephemeral data media can disappear, destroying human memory forever.

The experience of ancient civilizations confirms the significance of reliable data media. Unfortunately, humanity thinks in terms of «today», «tomorrow», «in 100 years» and nothing more. It is difficult to conceptualize preservation in terms of «a millennium» or «five thousand years». However, historians have no right to deprive future civilizations of the knowledge and information about the cultures which preceded them. 


\section{REFERENCES}

1. Albedil, M. F. (1994). Protoindiiskaia tsivilizatsiia: ocherki kultury [ProtoIndian civilization: essays on culture]. Moskva: Vostochnaia literatura. [in Russian].

2. Arbagi, M. (2011). The Catholic Church and the preservation of Mesoamerican archives: an assessment. Archival Issues, 33(2), 112-120. [in English].

3. Bautier, R.-H. (1970). La phase cruciale de l'histoire des archives: la constitution des dépôs d'archives et la naissance de l'archivistique (XVIe - début du XIXe siècle) [A decisive stage in the history of archives: the creation of archival repositories and the emergence of archival science (16th - early 19th centuries)]. Archivum, XVIII (1968), 139-149. [in French].

4. Brenneke, A. (1968). Archivistica. Contributo Alla Teoria ed Alla Storia Archivistica Europea [Archival science. Contribution to the theory and the research of history of European archives]. Milano. [in Italian].

5. Casanova, E. (1928). Archivistica. [Archival science] (2nd ed.). Siena. [in Italian].

6. Fournet, J.-L. (2018). Archives and Libraries in Greco-Roman Egypt. In Sabine Kienitz, Michael Friedrich, Christian Brockmann \& Alessandro Bausi (Ed.), Manuscripts and Archives: Comparative Views on Record-Keeping (pp. 171-200). De Gruyter. [in English].

7. Friedrich, M. (2018). The Birth of the Archive: A History of Knowledge (John Noel Dillon, Translator). Ann Arbor. [in English].

8. Joshi, J. P. \& Parpola, A. (Ed.) (1987). Corpus of Indus Seals and Inscriptions (Vol. 1). Collections in India. Helsinki: Suomalainen Tiedeakatemia. [in English].

9. Lodolini, E. (1991). Lineamenti di storia dell»archivistica italiana. Dalle origini alla metà del secolo $X X$ [The analytical review of the Italian history of archives. From the beginning intil the middle of the XX century]. [in Italian].

10. Lodolini, E. (2018). Storia dell'archivistica italiana. Dal mondo antico alla metà del secolo $X X$ [The history of Italian archival science. From the ancient world until the middle of the XX century]. Franco Angeli. [in Italian].

11. Menshikov, A. V. (2009). Arhivy Vizantii $X-X V$ vekov [Archives of Byzantium in $\mathrm{X}-\mathrm{XV}$ centuries] (Candidate's thesis). Moskva. [in Russian].

12. Montevecchi, O. (1988). La papirologia [Papyrology]. Vita e Pensiero. [in Italian].

13. Parpola, A., Pande, B. M. \& Koskikallio, P. (2010). Corpus of Indus Seals and Inscriptions (Vol. 3). New materials, untraced objects, and collections outside India and Pakistan. Helsinki: Suomalainen Tiedeakatemia. [in English].

14. Posner, E. (1972). Archives in the Ancient World. Cambridge, Massachusetts: Harvard University Press. [in English].

15. Rodriguez de, D. J. L. (1998). Evolución histórica del expediente [The historical evolution of legal proceedings]. Anuario de historia del derecho español, 68, 475-490. [in Spanish].

16. Sandri, L. (1958). La storia degli archive [The history of archives]. Istituto Polografico dello Stato. [in Italian]. 
17. Shan, S. G. M. \& Parpola, A. (Ed.) (1991). Corpus of Indus Seals and Inscriptions (Vol. 2). Collections in Pakistan. Helsinki: Suomalainen Tiedeakatemia. [in English].

18. Staack, T. (2016, April). Reconstruction of Early Chinese Bamboo and Wood Manuscripts: A Review (1900-2010). University Hamburg: Centre for the study of manuscript cultures. Retrieved from http://www.manuscript-cultures.unihamburg.de/papers_e.html [in English].

19. Starostin, E. V. (1997). Zarubezhnoe arhivovedenie [International archival science]. Moskva: IAI RGGU. [in Russian].

20. Starostin, E. V. (1999). Metodologiia istorii arhivov: periodizatsiia [The methodology of the history of archives: periodization]. Otechestvennyie arhivy, 6 , 4-12. [in Russian].

21. Urton, G. (2017) Inka history in knots, reading Khipus as primary sources. Austin. [in English].

22. Veenhof, K. R. (1986). Cuneiform Archives and Libraries. Abstract of Papers'83: The $30^{\text {th }}$ Rencontre Assyriologique Internationale Leiden. Nederlands Instituut voor het Nabije Oosten, Leiden. [in English].

23. Wa, Ye. \& Esherick, J. W. (1996). Chinese Archives. An Introductory Guide. Berkeley: Institute of East Asian Studies University of California. [in English].

Лариса Левченко докторка історичних наук, професорка, заступниця Голови, Державна архівна служба України; професорка кафедри історії, Чорноморський національний університет імені Петра Могили ORCID: https://orcid.org/0000-0001-9097-7373

\section{ПРИКЛАД ПЕРІОДИЗАЦІЇ ВСЕСВІТНЬОЇ ІСТОРІЇ АРХІВІВ У СВІТЛІ ЦИВІЛІЗАЦІЙНОГО ПІДХОДУ ТА ЕВОЛЮЦІЇ НОСІЯ ІНФОРМАЦІї}

Анотація. Метою дослідження $є$ розроблення варіанту періодизації всесвітньої історії архівів із урахуванням цивілізаційного підходу та еволюції матеріального носія інформації. Методологія дослідження базується на пропозиціях радянсько-російського історика-архівіста Євгенія Старостіна щодо врахування носія інформації у виробленні періодизації історії архівів, а також ідеях цивілізаціоністів. Наукова новизна полягає у розробленні періодизації всесвітньої історії архівів у горизонтальній площині, яка враховує взаємодію та взаємовпливи цивілізації, а також демонструє кінцевий результат їхніх архівних зусиль. Крім того, визначено носій інформації, типовий для кожної цивілізації. Висновок. Застосовуючи цивілізаційний підхід до розроблення періодизації всесвітньої історії архівів, учені звільняються від необхідності будувати лінійні (висхідні) моделі з жорсткими зв'язками між компонента- 
ми. Оскільки кожна цивілізація є унікальною, автономною, самодостатньою та самокерованою системою, можливе створення періодизації історії архівів у горизонтальній площині. У такий спосіб допустимо додавання нових або подрібнення існуючих компонентів.

Історія людства демонструє взаємний вплив цивілізацій; цивілізаційні конфлікти часто мали руйнівні наслідки в сфері збереження колективної пам’яті людства та передавання їі наступним поколінням. Іноді цивілізації самостійно знищували свою історичну спадщину. Однак, переважно руйнування архівів спричиняв нещадний час. Зважаючи на цей факт, неможливо ігнорувати роль носія інформації, який набуває у такому разі значення ключового критерію для створення періодизації всесвітньої історії архівів. Не слід забувати, що реалізація функції збереження документів визначається переважно природою носія інформації.

У представленому варіанті періодизації до уваги взято 10 цивілізацій, включаючи сучасну. Для кожної визначено притаманний ій носій інформації. Таким чином, запропонований варіант періодизації є таким: «епоха глиняних табличок» - месопотамська цивілізація (6000-300 рр. до н. е.); «епоха папірусу» - єгипетська цивілізація (5500-300 рр. до н. е.); «епоха дерев'яної табули» - греко-римська (класична) цивілізація (1500(1100) до н. е. - (500)600 н. е.); «епоха стеатитових табличок» - цивілізація Долини Інду (Хараппа) (3700-1300 рр. до н. е.); «епоха бамбукових листків»-Стародавня китайська цивілізація (2000 р. до н. е. - 400 р. н. е.); «епоха Амату»-Мезоамериканська цивілізація (1000 р. до н. е. - 1550 р. н. е.); «епоха кіпу» - Андська цивілізація (3700-1800 рр. до н. е.); «епоха засмаглого пергаменту» - Візантійська цивілізація (395-1453); «епоха паперу» - Північно-західна цивілізація Старого Світу (західна, православна та ісламська) (від Різдва Христового до кінця ХХ ст.); «епоха цифрових носіїв інформації» - Сучасна цивілізація (починаючи від кінця XX - початку XXI ст. й далі).

Ключові слова: всесвітня історія архівів; періодизація історії архівів; архіви цивілізацій. 